Creative commons User License: CC BY-NC-ND

Abstracted by: EBSCOhost, Electronic Journals Service (EJS),

Google Scholar, Directory of Open Access Journals (DOAJ),

Journal Seek, Scientific Commons

Food and Agricultural Organization (FAO), CABI and Scopus
Journal of Agricultural Extension

Vol. XX (X) XXXXXX, 20XX

ISSN(e): 24086851; ISSN(Print); 1119944X

http://journal.aesonnigeria.org

http://www.ajol.info/index.php/jae

Email: editorinchief@aesonnigeria.org

\title{
Wellbeing of Beneficiaries of the University Based Agricultural Extension System in Ogun State, Nigeria
}

http://dx.doi.org/10.4314/jae.v20i2.11

\section{Akinbile, L.A.}

Department of Agricultural Extension and Rural Development

University of Ibadan.

Email: lakinbile@yahoo.com, +23480232250454

\section{Oyebode L.A.}

Department of Agriculture, College of Agriculture Food Science and Technology,

Wesley University Ondo.

Email: abiodunoyebode@gmail.com, +2348067405322

\section{Sobiye A.A.}

Department of Agricultural Extension and Rural Development University of Ibadan.

Email:sobiyeafeez@gmail.com, +2348154447950

\section{Abstract}

The study assessed the wellbeing of farmers under the University Based Agricultural Extension System in selected communities in Ogun State. Multistage sampling procedure was deployed in sampling 60 each of UBAES and ADP beneficiaries. Interview schedule was used to gather data which was analyzed using both descriptive and inferential statistics at $P=0.05$. UBAES beneficiaries mainly accessed training on harnessing farmers groups for increased production $(\bar{x}=2.72)$, family welfare and food nutrition programme $(\bar{x}=2.67)$ while their ADP counterparts had capacity building on financing agricultural production $(\bar{x}=2.65)$ and training on harnessing farmers group for increased production ( $\bar{x}=2.37)$. Increased access to agricultural credit $(\bar{x}=1.67)$ and enhanced production skill $(\bar{x}=1.53)$ were benefits derived by ADP beneficiaries while UBAES beneficiaries had improved level of living $(\bar{x}=1.88)$ and increase in crop production $(\bar{x}=1.87)$ as benefits derived. UBAES beneficiaries were better off in material (81.7\%), social (76.7\%) and psychological (83.3\%) wellbeing, while ADP beneficiaries were better off in economic (65.0\%) wellbeing. Significant relationship existed between the estimated monthly income ( $r=0.249)$, frequency of service accessed $(r=0.0314)$ and wellbeing under UBAES. Significant difference $(p=0.000)$ was established between the wellbeing of UBAES and ADP beneficiaries. UBAES is considered a more potent platform for enhancing farmers' wellbeing.

Key words: UBAES beneficiaries, ADP beneficiaries, Extension Activities, Wellbeing 
Creative commons User License: CC BY-NC-ND

Abstracted by: EBSCOhost, Electronic Journals Service (EJS),

Google Scholar, Directory of Open Access Journals (DOAJ),

Journal Seek, Scientific Commons,

Food and Agricultural Organization (FAO), CABI and Scopus
Journal of Agricultural Extension

Vol. XX (X) XXXXXX, 20XX

ISSN(e): 24086851; ISSN(Print); 1119944X

http://journal.aesonnigeria.org

http://www.ajol.info/index.php/jae

Email: editorinchief@aesonnigeria.org

\section{Introduction}

The agricultural sector is a crucial mainstay of local livelihoods and National Gross Domestic Product (GDP) of many countries in Africa (Mendelsohn et al., 2000; Devereux and Maxwell, 2001). Owing to these huge potentials it is however noted that the development of the sector cannot be achieved without an efficient and effective extension system (Koyenikan, 2008).

It is pertinent to ensure that the upward production capacity of agricultural produce is achieved so that the issues of unemployment, food insecurity, low agricultural productivity, economic deficiency, rural underdevelopment etc. are brought to the barest minimum in Nigeria. The possibility of doing this won't be without the efforts of agricultural professionals called Agricultural Extension Agents who work with different agencies. They undertake the duty of disseminating innovations in Agriculture and seeing to the development of our rural areas through visionary and focus driven programmes that are targeted at meeting and fitting into the needs of farmers especially those in the rural areas.

Agricultural Development Programme (ADP) represented the first major practical demonstration of the integrated approach to agricultural development in Nigeria. The experiment which started with World Bank funding, with projects at Funtua, Gusau and Gombe in 1974, blossomed into Ayangba (1977), Lafia (1977), Bida (1979), Ilorin (1980), Ekiti-Akoko (1981) and Oyo-North (1982) agricultural development projects. Following successful negotiations for multi-state agricultural development projects with the World Bank, each state of the country, and the Federal Capital, Abuja, now has one ADP.

The University Based Agricultural Extension Service (UBAES) that takes place in Nigeria in different higher institutions of learning have been adopted in different forms and serve different purposes ranging from researches, corporate social responsibility, training and farm demonstration, extension programme etc. The Federal University of Agriculture, Abeokuta (FUNAAB) has a dedicated department with the name Agricultural Media Resources and Extension Centre (AMREC) with 
Creative commons User License: CC BY-NC-ND

Abstracted by: EBSCOhost, Electronic Journals Service (EJS),

Google Scholar, Directory of Open Access Journals (DOAJ),

Journal Seek, Scientific Commons,

Food and Agricultural Organization (FAO), CABI and Scopus
Journal of Agricultural Extension

Vol. XX (X) XXXXXX, 20XX

ISSN(e): 24086851; ISSN(Print); 1119944X

http://journal.aesonnigeria.org

http://www.ajol.info/index.php/jae

Email: editorinchief@aesonnigeria.org

adopted communities such as Alabata, Isolu, Opeji and Odeda. The University of Ibadan has adopted Ileogbo Community; University of Ife has adopted Isoya community. Other Universities that are involved in UBAES according to Akinnagbe and Ajayi (2010) are University of Ilorin, Michael Okpara University of Agriculture and University of Agriculture Makurdi. The Micheal Okpara University of Agriculture, Umudike (MOUAU) also has its own department with the name MOUAU Extension Center (MEC) with adopted communities like Umuariaga, Umudike and Amakama all in Ikwuano and Umuahia South Local Government areas of Abia State. The essence of UBAES and ADP are to engage in programmes that will see to the improvement of well-being through improved food security, improved health awareness, community development, and practical technology transfer among other things. The import of this connection is to ensure that there is a direct relationship between these programmes and well-being of the rural families. The university environment is a place where most of these researches emanate from and the nearness to researchers or subject matter specialists to end-users should serve as an edge to other forms of extension service delivery platforms.

The main focus of agricultural extension is to proffer solution to the myriad of challenges confronting the rural populations especially the farm families. Considering the objectives of these UBAES and ADP, it is only expected that the impact of the adoption of their innovations and services will lead to a significant improvement in the wellbeing of its recipients, reduce poverty, improve health, increase food production and security. It is important that the two media are compared with respect to how well each of them succeed in influencing the wellbeing of beneficiaries and which of them perform better.

\section{Purpose of the study}

The study investigated the activities of these service providers on the wellbeing of its beneficiaries.

Specifically the objectives were:

1. determine beneficiaries access to extension activities;

2. identify benefits derived by beneficiaries from extension activities;

3. identify constraints to accessing extension activities; and 
Creative commons User License: CC BY-NC-ND

Abstracted by: EBSCOhost, Electronic Journals Service (EJS),

Google Scholar, Directory of Open Access Journals (DOAJ),

Journal Seek, Scientific Commons,

Food and Agricultural Organization (FAO), CABI and Scopus
Journal of Agricultural Extension

Vol. XX (X) XXXXXX, 20XX

ISSN(e): 24086851; ISSN(Print); 1119944X

http://journal.aesonnigeria.org

http://www.ajol.info/index.php/jae

Email: editorinchief@aesonnigeria.org

4. determine beneficiaries wellbeing.

\section{Methodology}

The study area is Ogun State in South-West Nigeria. The vegetation pattern is that of rain forest in the south and Guinea Savannah in the north, with two distinct climate seasons. The prevailing climate and soil characteristics support the cultivation of food crops and tree crops like cocoa, oil palm, kola nut, walnut and citrus. Other agricultural activities that thrive in the state include fish farming, livestock production, agro processing etc. Multi stage sampling procedure was deployed in the sampling of beneficiaries. The first stage involved the purposive sampling of Odeda and Abeokuta North Local Government to represent beneficiaries of UBAES under the Federal University of Agriculture, Abeokuta adopted communities and Ewekoro Local Government to represent ADP beneficiaries because of its functional ADP block. The second stage involved the random sampling of three communities each from the two local government areas that represent UBAES and six communities from the local government area that represent ADP. The final stage involved the random sampling of ten beneficiaries each from the selected communities via table of random numbers, making a total of 60 beneficiaries of UBAES and 60 beneficiaries of ADP.

Variables assessed include respondents' socio economic characteristics, beneficiaries access to extension services which was operationalized as high (for services accessed within a span of 3 months interval), moderate (for services accessed within a span of 6 months interval) and low (for services accessed beyond 6 months span) and weighted mean was used to rate beneficiaries access to these activities, benefits derived from activities accessed was operationalized as high, moderate and low with scores of 2,1 and 0 assigned respectively, weighted mean was calculated and used as rating criterion, constraints to accessing extension activities provided was scaled as degree of severity (very severe, severe, not severe and not a constraint with scores of 3,2,1 and 0 assigned ) from a list of constraints provided, weighted mean was calculated and used in ranking of the constraints. Beneficiaries' well-being was operationalized by adapting scales of Core Welfare Indicator Questionnaire (NBS,2006) and Ryffs scale of Psychological wellbeing 
Creative commons User License: CC BY-NC-ND

Abstracted by: EBSCOhost, Electronic Journals Service (EJS),

Google Scholar, Directory of Open Access Journals (DOAJ),

Journal Seek, Scientific Commons,

Food and Agricultural Organization (FAO), CABI and Scopus
Journal of Agricultural Extension

Vol. XX (X) XXXXXX, 20XX

ISSN(e): 24086851; ISSN(Print); 1119944X

http://journal.aesonnigeria.org

http://www.ajol.info/index.php/jae

Email: editorinchief@aesonnigeria.org

(1995) under 4 domains namely: material (properties owned and types i.e. house, cars, farm size etc.), economic (meals taken ,schools their children attend, utilities enjoyed etc.), social (impact in the society they live in, community projects executed etc.) and psychological (purpose in life, self acceptance, environmental sanitation etc.). Scores were obtained from these domains, standardized, aggregated and mean was used to categorize wellbeing as good, for values up to the mean and above, and poor for values below the mean. This is aimed at depicting the contribution of these extension service providers to beneficiaries' wellbeing.

\section{Socio-economic characteristics of respondents}

As revealed in Table 1, the majority of the respondents were adults with mean ages of 54.33 and 51.66 years for ADP and UBAES beneficiaries, respectively. This is not an encouraging signal because they are not in their active age range and this may portend danger as to enhancing their well being. This view is supported by Bature, Sanni, and Adebayo (2013) that people in their 40s have the highest aspirations and anxieties and thus have the highest tendency to seek help to achieve their aspirations as well as kill their anxieties. Also, there are more male than female beneficiaries with $86.7 \%$ for UBAES and $80.0 \%$ for ADP beneficiaries. The majority $(90.0 \%$ for UBAES and $76.7 \%$ for ADP) of the respondents were married. Respondents had a fairly large (53.3\% for UBAES and $51.6 \%$ for ADP) household size of 1-6, which depicts that they have responsibilities to cater for, hence they are likely to key into any service delivery platform to enhance their wellbeing. Majority $(71.7 \%)$ of the ADP respondents do not have formal education, compared to a fraction $(13.3 \%)$ of their UBAES counterparts. On the whole, beneficiaries under UBAES had more formal education than their ADP counterpart. It is viewed that these beneficiaries engaged in other formal endeavors but take advantage of UBAES to engage in agricultural production. The Average monthly income of the respondents (UBAES and ADP) is $\$ 69,377.97 \mathrm{k}$ and $\$ 17,600.83 \mathrm{k}$, respectively. This shows that UBAES beneficiaries make substantial amount of money from their agricultural activities, which can be attributed to the diverse livelihood activities they engaged in. This assertion is in tandem with the findings of Adi (2007) and Zerihun (2012) who stated that majority of the people in rural and peri-urban areas had rich 
Creative commons User License: CC BY-NC-ND

Abstracted by: EBSCOhost, Electronic Journals Service (EJS),

Google Scholar, Directory of Open Access Journals (DOAJ),

Journal Seek, Scientific Commons,

Food and Agricultural Organization (FAO), CABI and Scopus
Journal of Agricultural Extension

Vol. XX (X) XXXXXX, 20XX

ISSN(e): 24086851; ISSN(Print); 1119944X

http://journal.aesonnigeria.org

http://www.ajol.info/index.php/jae

Email: editorinchief@aesonnigeria.org

natural capital that shapes their livelihood activity choices in the direction of agriculture.

Table 1: Socio-economic characteristics of respondents

\begin{tabular}{|c|c|c|c|}
\hline & UBAES $n=60 \%$ & ADP $n=60 \%$ & MEAN \\
\hline \multicolumn{4}{|l|}{ Age } \\
\hline $30-39$ & 10 & 10 & UBAES \\
\hline $40-49$ & 28.3 & 15 & 51.66 years \\
\hline $50-59$ & 44.4 & 46.7 & ADP \\
\hline $60-69$ & 6.6 & 23.3 & 54.33 years \\
\hline $70-79$ & 6.7 & 5 & \\
\hline \multicolumn{4}{|l|}{ Sex } \\
\hline Male & 86.7 & 80 & \\
\hline Female & 13.3 & 20 & \\
\hline \multicolumn{4}{|l|}{ Marital status } \\
\hline Single & 3.3 & 5.0 & \\
\hline Married & 90.0 & 76.7 & \\
\hline Divorced & 3.3 & 1.7 & \\
\hline Widowed & 3.3 & 16.7 & \\
\hline \multicolumn{4}{|l|}{ Household size } \\
\hline $1-5$ & 35 & 21.7 & UBAES $=7$ \\
\hline $6-10$ & 53.3 & 51.6 & $A D P=8.25$ \\
\hline $11-15$ & 8.4 & 26.7 & \\
\hline $16-20$ & 3.3 & -- & \\
\hline \multicolumn{4}{|l|}{ Educational status } \\
\hline No formal education & 13.3 & 71.7 & \\
\hline Primary & 21.7 & 23.3 & \\
\hline Secondary & 36.7 & 5.0 & \\
\hline Tertiary & 28.3 & -- & \\
\hline Estimated monthly income ( & $\%$ & $\%$ & \\
\hline $1-20,000$ & 6.7 & 67.8 & UBAES \\
\hline $20,001-40,000$ & 21.7 & 30.5 & 699,377.97k \\
\hline $40,001-60,000$ & 21.7 & 3.3 & ADP \\
\hline $60,001-80,000$ & 15.0 & -- & $\# 17,600.83 \mathrm{k}$ \\
\hline $80,001-100,000$ & 15.0 & -- & \\
\hline $100,001-120,000$ & 11.7 & -- & \\
\hline $120,001-140,000$ & 1.7 & -- & \\
\hline $140,001-160,000$ & 6.7 & -- & \\
\hline $160,001-180,001$ & 1.7 & -- & \\
\hline $180,001-200,001$ & 1.7 & -- & \\
\hline
\end{tabular}

Source: Field Survey, 2015. 
Creative commons User License: CC BY-NC-ND

Abstracted by: EBSCOhost, Electronic Journals Service (EJS),

Google Scholar, Directory of Open Access Journals (DOAJ),

Journal Seek, Scientific Commons,

Food and Agricultural Organization (FAO), CABI and Scopus
Journal of Agricultural Extension

Vol. XX (X) XXXXXX, 20XX

ISSN(e): 24086851; ISSN(Print); 1119944X

http://journal.aesonnigeria.org

http://www.ajol.info/index.php/jae

Email: editorinchief@aesonnigeria.org

\section{Extension activities accessed}

Table 2 reveals that UBAES beneficiaries recorded high access on the following activities: training on harnessing farmers groups for increased production $(\bar{x}=2.72)$, family welfare and food nutrition programme $(\bar{x}=2.67)$ training workshop before planting season and adult literacy programme $(\bar{x}=2,65)$, it's plausible to say that these activities form the core mandate of UBAES, however they had low access to capacity building for financing agricultural production $(\bar{x}=1.55)$. This finding is in tandem with Cunninggham, Oosthuizen and Taylor (2009) that right from inception, University Based Agricultural Extension System has been broad based, incorporating adult education, nutrition, home economics, agricultural extension, development communication and health activities. Capacity building for financing agricultural production ( $\bar{x}=2.65$ ), training on harnessing farmers group for increased production $(\bar{x}=2.37)$ were activities accessed most by ADP beneficiaries, on the contrary training on enhancing marketing skills $(\bar{x}=1.17)$, family welfare and food nutrition programme $(\bar{x}=1.20)$ and training on improving soil fertility $(\bar{x}=1.28)$ recorded low access, this can partly be attributed to the reduced number of extension agents, this view is supported by Umeh O.J. et al. (2015) that due to poor staff disposition in Enugu State ADP, farm visits were greatly minimized to only the circles occupied by the available EAs. This could be attributed to UBAES skill empowerment and capacity building activities as against cash empowerment and input subsidy deployed by ADP. 
Creative commons User License: CC BY-NC-ND

Abstracted by: EBSCOhost, Electronic Journals Service (EJS), Google Scholar, Directory of Open Access Journals (DOAJ), Journal Seek, Scientific Commons,

Food and Agricultural Organization (FAO), CABI and Scopus
Journal of Agricultural Extension

Vol. XX (X) XXXXXX, 20XX

ISSN(e): 24086851; ISSN(Print); 1119944X

http://journal.aesonnigeria.org

http://www.ajol.info/index.php/jae

Email: editorinchief@aesonnigeria.org

Table 2: Extension activities accessed

\begin{tabular}{|c|c|c|c|c|c|}
\hline \multirow[t]{2}{*}{ Extension activities } & Service & \multicolumn{2}{|c|}{ Frequency of access } & \multicolumn{2}{|c|}{$\mathrm{n}=60$} \\
\hline & & High \% & Moderate \% & Low \% & Weighted mean \\
\hline Capacity building on financing & UBAES & 15.0 & 25.0 & 60.0 & 1.55 \\
\hline agricultural production & ADP & 71.7 & 21.7 & 6.7 & 2.65 \\
\hline Training on improved processing of & UBAES & 63.3 & 28.3 & 8.3 & 2.55 \\
\hline farm produce & ADP & 13.3 & 61.7 & 25 & 1.88 \\
\hline Training workshop before planting & UBAES & 68.3 & 28.3 & 3.3 & 2.65 \\
\hline season. & ADP & 38.3 & 45.0 & 16.7 & 2.22 \\
\hline Farmers health & UBAES & 66.7 & 30.0 & 3.3 & 2.63 \\
\hline programme & ADP & 50.0 & 28.3 & 21.7 & 2.15 \\
\hline Family welfare and food nutrition & UBAES & 68.3 & 30.0 & 1.7 & 2.67 \\
\hline programme & ADP & 8.3 & 3.3 & 88.3 & 1.20 \\
\hline Training on improved soil fertility & UBAES & 55.0 & 40.0 & 5.0 & 2.50 \\
\hline & ADP & -- & 28.3 & 71.7 & 1.28 \\
\hline Training on harnessing farmers & UBAES & 73.3 & 25.0 & 1.7 & 2.72 \\
\hline groups' for increased production. & ADP & 51.7 & 33.3 & 15.0 & 2.37 \\
\hline Training on enhancing marketing & UBAES & 51.7 & 28.3 & 20.0 & 2.32 \\
\hline skills & ADP & -- & 16.7 & 83.3 & 1.17 \\
\hline Adult literacy programme & UBAES & 70.0 & 25.0 & 5.0 & 2.65 \\
\hline & ADP & 31.7 & 50.0 & 18.3 & 2.13 \\
\hline Capacity building workshop on & UBAES & 56.7 & 38.3 & 5.0 & 2.52 \\
\hline improved cassava processing. & ADP & 18.7 & 66.7 & 15.0 & 2.03 \\
\hline
\end{tabular}

Source: Field Survey, 2015. 
Creative commons User License: CC BY-NC-ND

Abstracted by: EBSCOhost, Electronic Journals Service (EJS),

Google Scholar, Directory of Open Access Journals (DOAJ),

Journal Seek, Scientific Commons,

Food and Agricultural Organization (FAO), CABI and Scopus
Journal of Agricultural Extension

Vol. XX (X) XXXXXX, 20XX

ISSN(e): 24086851; ISSN(Print); 1119944X

http://journal.aesonnigeria.org

http://www.ajol.info/index.php/jae

Email: editorinchief@aesonnigeria.org

\section{Benefits derived from extension activities accessed}

Results on Table 3 reveal that improved level of living $(\bar{x}=1.88)$ and increase in crop production $(\bar{x}=1.87)$ were benefits derived by UBAES beneficiaries from extension activities accessed. Increased access to agricultural credit $(\bar{x}=1.67)$, enhanced production skill ( $\bar{x}=1.53)$ and enhanced processing capacity $(\bar{x}=1.48)$ were benefits derived by ADP beneficiaries from extension activities accessed. The observed trend of benefits acquired is attributed to the beneficiaries being involved in ADP anchored programmes like NSPFS, NPFS, RTEP etc. UBAES beneficiaries recorded low benefit under access to agricultural credit $(\bar{x}=1.42)$ and enhanced marketing skill $(\bar{x}=1.43)$. It is worthy to note that increase in crop production $(\bar{x}=0.33)$ and enhanced marketing skill $(\bar{x}=0.63)$ were activities that recorded low benefit by ADP beneficiaries, with this it suffice to say that despite the activities accessed by ADP beneficiaries it did not translate to increase in the scale of their production. 
Creative commons User License: CC BY-NC-ND

Abstracted by: EBSCOhost, Electronic Journals Service (EJS),

Google Scholar, Directory of Open Access Journals (DOAJ),

Journal Seek, Scientific Commons,

Food and Agricultural Organization (FAO), CABI and Scopus
Journal of Agricultural Extension

Vol. XX (X) XXXXXX, 20XX

ISSN(e): 24086851; ISSN(Print); 1119944X

http://journal.aesonnigeria.org

http://www.ajol.info/index.php/jae

Email: editorinchief@aesonnigeria.org

Table 3: Benefits derived from extension activities accessed

\begin{tabular}{lll}
\hline Benefits derived & Service providers & Weighted mean \\
\hline Increase in crop production & UBAES & 1.87 \\
& ADP & 0.33 \\
Improved level of living & UBAES & 1.88 \\
& ADP & 1.20 \\
Increased income & UBAES & 1.78 \\
& ADP & 0.88 \\
Increased access to & UBAES & 1.42 \\
agricultural credit & ADP & 1.67 \\
& & \\
Enhanced production skill & UBAES & 1.72 \\
& ADP & 1.53 \\
Enhanced marketing skill & UBAES & 1.43 \\
& ADP & 0.63 \\
Enhanced processing & UBAES & 1.63 \\
capacity & ADP & 1.48 \\
Access to health care & UBAES & 1.57 \\
Improve household food & ADP & 0.72 \\
security & ABAES & 1.60 \\
Ability to acquire assets & UBAES & 0.80 \\
(farm land) & ADP & 1.45 \\
Increased participation in & UBAES & 0.78 \\
social and communal & ADP & 1.40 \\
activities & & \\
\hline
\end{tabular}

\section{Constraints to accessing extension activities}

The intermittent supply of extension service $(\bar{x}=1.32)$ and lack of information on service provider schedule $(\bar{x}=1.25)$ ranked highest as constraints faced by UBAES beneficiaries in accessing extension activity, while high interest rate on loans $(\bar{x}$ $=2.57)$ and low credit facilities $(\bar{x}=2.30)$ were ranked highest by ADP beneficiaries. Conversely, health condition of farmers $(\bar{x}=0.38)$ and inadequate extension personnel during training $(\bar{\chi}=0.47)$ ranked least as constraints faced by UBAES 
Creative commons User License: CC BY-NC-ND

Abstracted by: EBSCOhost, Electronic Journals Service (EJS), Google Scholar, Directory of Open Access Journals (DOAJ), Journal Seek, Scientific Commons,

Food and Agricultural Organization (FAO), CABI and Scopus
Journal of Agricultural Extension

Vol. XX (X) XXXXXX, 20XX

ISSN(e): 24086851; ISSN(Print); 1119944X

http://journal.aesonnigeria.org

http://www.ajol.info/index.php/jae

Email: editorinchief@aesonnigeria.org

beneficiaries to accessing extension activities, while lack of information on service providers schedule $(\bar{x}=0.33)$ and poor coverage of training on all aspects of production activity $(\bar{x}=0.43)$ ranked least as constraints faced by ADP beneficiaries. This study is corroborated by Fadiji and Adeniji (2011) that inadequacies of extension programmes could be due to defect in programmes planning, implementation and evaluation. Also, Nxumalo and Oladele (2013) were of the opinion that farmers are faced with numerous constraints in a bid to participate in extension programmes.

\section{Table 4: Constraints to accessing extension activities}

\begin{tabular}{|c|c|c|}
\hline Constraints faced & Service providers & Weighted Mean \\
\hline Lack of information on service providers schedule & $\begin{array}{l}\text { UBAES } \\
\text { ADP }\end{array}$ & $\begin{array}{l}1.25 \\
0.33\end{array}$ \\
\hline Inadequate training gadgets & $\begin{array}{l}\text { UBAES } \\
\text { ADP }\end{array}$ & $\begin{array}{l}0.72 \\
0.98\end{array}$ \\
\hline Inadequate extension personnel during training & $\begin{array}{l}\text { UBAES } \\
\text { ADP }\end{array}$ & $\begin{array}{l}0.47 \\
0.50\end{array}$ \\
\hline Intermittent supply of extension service & $\begin{array}{l}\text { UBAES } \\
\text { ADP }\end{array}$ & $\begin{array}{l}1.32 \\
1.72\end{array}$ \\
\hline Health condition of farmers & $\begin{array}{l}\text { UBAES } \\
\text { ADP }\end{array}$ & $\begin{array}{l}0.38 \\
0.90\end{array}$ \\
\hline $\begin{array}{l}\text { Poor coverage of training on all aspects of production } \\
\text { activity }\end{array}$ & $\begin{array}{l}\text { UBAES } \\
\text { ADP }\end{array}$ & $\begin{array}{l}0.55 \\
0.43\end{array}$ \\
\hline Low credit facilities & $\begin{array}{l}\text { UBAES } \\
\text { ADP }\end{array}$ & $\begin{array}{l}1.08 \\
2.30\end{array}$ \\
\hline High interest rate on loans & $\begin{array}{l}\text { UBAES } \\
\text { ADP }\end{array}$ & $\begin{array}{l}0.70 \\
2.57\end{array}$ \\
\hline
\end{tabular}

Source: Field Survey, 2015. 
Creative commons User License: CC BY-NC-ND

Abstracted by: EBSCOhost, Electronic Journals Service (EJS), Google Scholar, Directory of Open Access Journals (DOAJ), Journal Seek, Scientific Commons,

Food and Agricultural Organization (FAO), CABI and Scopus
Journal of Agricultural Extension

Vol. XX (X) XXXXXX, 20XX

ISSN(e): 24086851; ISSN(Print); 1119944X

http://journal.aesonnigeria.org

http://www.ajol.info/index.php/jae

Email: editorinchief@aesonnigeria.org

\section{Beneficiaries' wellbeing}

Categorization of wellbeing under the four domains reveal that UBAES beneficiaries were better off than their ADP beneficiaries on material wellbeing (UBAES with 81.7\%, ADP with 68.3\%), social wellbeing (UBAES=76.7\%, ADP=58.3\%) and psychological wellbeing (UBAES=83.3\%, ADP=55.0\%). Conversely, ADP beneficiaries were better off though marginally on their economic wellbeing (UBAES $=55.0 \%, A D P=65.0 \%$ ) than their UBAES beneficiaries. The reason for this trend across domains is attributed to the mode of implementing the mandate of UBAES which cuts across these domains. This assertion is also established by Cunninggham, et al. (2009) that right from inception, University Based Agricultural Extension System has been broad based, incorporating adult education, nutrition, home economics, agricultural extension, development communication and health services. Also corroborating the above assertion, Akpoko and Kudi (2007) noted that University Based Agricultural Extension System (UBAES) has much potential for success because information is being assembled, systematized and made available on best agricultural practices suited to a particular environment based on accumulation of experience and finding from research.

\section{Table 5: Beneficiaries wellbeing}

\begin{tabular}{lllll}
\hline \multicolumn{1}{c}{ Domain } & $\begin{array}{l}\text { Material } \\
\text { wellbeing }\end{array}$ & $\begin{array}{l}\text { Economic } \\
\text { wellbeing }\end{array}$ & $\begin{array}{l}\text { Social } \\
\text { wellbeing }\end{array}$ & $\begin{array}{l}\text { Psychological } \\
\text { Wellbeing }\end{array}$ \\
\hline $\begin{array}{llll}\text { UBAES Beneficiaries } \\
\text { Poor: freq (\%) }\end{array}$ & $11(18.3)$ & $27(45.0)$ & $14(23.3)$ & $7(11.7)$ \\
Good: Freq (\%) & $49(81.7)$ & $33(55.0)$ & $46(76.7)$ & $53(88.3)$
\end{tabular}

\section{ADP Beneficiaries}

\begin{tabular}{|c|c|c|c|c|}
\hline Poor: freq (\%) & $19(31.7)$ & $21(35.0)$ & $25(41.7)$ & $27(45.0)$ \\
\hline Good: Freq (\%) & 41 (68.3) & $39(65.0)$ & 35 (58.3) & $33(55.0)$ \\
\hline
\end{tabular}

Source: Field survey, 2015. 
Creative commons User License: CC BY-NC-ND

Abstracted by: EBSCOhost, Electronic Journals Service (EJS),

Google Scholar, Directory of Open Access Journals (DOAJ),

Journal Seek, Scientific Commons,

Food and Agricultural Organization (FAO), CABI and Scopus
Journal of Agricultural Extension

Vol. XX (X) XXXXXX, 20XX

ISSN(e): 24086851; ISSN(Print); 1119944X

http://journal.aesonnigeria.org

http://www.ajol.info/index.php/jae

Email: editorinchief@aesonnigeria.org

\section{Test of hypotheses}

Results indicate that significant relationship $(r=.0249, p=0.054)$ is established between estimated monthly income of UBAES beneficiaries and their wellbeing. This implies that the estimated monthly income of UBAES beneficiaries translated to their wellbeing, indicating that as income increases, their wellbeing increases. Significant relationship also exists between extension activities accessed by UBAES beneficiaries $(r=.0 .671)$, benefits derived from activities accessed $(r=.0 .139)$ and their wellbeing. This can be adduced to activities accessed by UBAES beneficiaries who cut across the domains of wellbeing. Table 7 established a significant difference in the wellbeing of the beneficiaries, with this established, it suffices to say that the wellbeing of these beneficiaries are at variance from each other. This can be attributed to the mandate, coverage and mode of implementation of the extension activities by UBAES This view is supported by Cunninggham, et al. (2009) that right from inception, University Based Agricultural Extension System has been broad based, incorporating adult education, nutrition, home economics, agricultural extension, development communication and health services. 
Creative commons User License: CC BY-NC-ND

Abstracted by: EBSCOhost, Electronic Journals Service (EJS),

Google Scholar, Directory of Open Access Journals (DOAJ),

Journal Seek, Scientific Commons,

Food and Agricultural Organization (FAO), CABI and Scopus
Journal of Agricultural Extension

Vol. XX (X) XXXXXX, 20XX

ISSN(e): 24086851; ISSN(Print); 1119944X

http://journal.aesonnigeria.org

http://www.ajol.info/index.php/jae

Email: editorinchief@aesonnigeria.org

Table 6: Relationship between independent variables and beneficiaries wellbeing.

Variable

Estimated monthly income

UBAES

ADP

Extension activities accessed

UBAES

ADP

Benefits derived from activities accessed

UBAES

ADP

Constraints to accessing activities

UBAES

ADP
$0.139^{*}$

0.627

0.114

$0.249^{*}$

$-0.135$

$0.671^{*}$

0.067

0.057

* Significant variables. Source: Field survey (2015).

Table 7: T-test for difference between wellbeing of UBAES and ADP beneficiaries.

\begin{tabular}{lccccc}
\hline $\begin{array}{c}\text { Service } \\
\text { providers }\end{array}$ & No of Cases & Df & Mean & Mean Diff & t-value \\
UBAES & 60 & 59 & 1.7000 & & \\
ADP & 60 & 59 & 1.5833 & 0.1167 & $28.495^{\star}$ \\
\hline Source: Field survey (2015) & & & &
\end{tabular}

\section{Conclusion and Recommendations}

The study established that UBAES beneficiaries had access to activities that harness potentials of farmer groups for increased production and adult literacy, while ADP beneficiaries had access to activities that enhance capacity building for financing 
Creative commons User License: CC BY-NC-ND

Abstracted by: EBSCOhost, Electronic Journals Service (EJS),

Google Scholar, Directory of Open Access Journals (DOAJ),

Journal Seek, Scientific Commons,

Food and Agricultural Organization (FAO), CABI and Scopus
Journal of Agricultural Extension

Vol. XX (X) XXXXXX, 20XX

ISSN(e): 24086851; ISSN(Print); 1119944X

http://journal.aesonnigeria.org

http://www.ajol.info/index.php/jae

Email: editorinchief@aesonnigeria.org

agricultural production. Improved level of living was benefit derived by UBAES beneficiaries, while increase in access to agricultural credit was benefit derived by ADP beneficiaries. UBAES beneficiaries were constrained by intermittent supply of extension activities and lack of information on service providers' schedule, while ADP beneficiaries were constrained by high interest rate on loan and low credit facilities. UBAES beneficiaries had better material, social and psychological wellbeing. There was significant relationship between estimated monthly income, extension activities accessed, benefits derived and wellbeing of UBAES beneficiaries. From the foregoing, it is recommended that there should be regular supply of extension activities to enhance beneficiaries' access to extension activities, information on service providers' schedule should be provided to beneficiaries to enhance access to extension activities. It is also recommended that other complementary activities relating to wellbeing should also be given priority by ADP.

\section{References}

Adi, B. (2007): Determinants of agricultural and non agricultural livelihood strategies in rural communities: Evidence from Eastern Nigeria. 140(2), 93-109.

Akinnagbe, O.M. and Ajayi, A.R. (2010). Challenges of beneficiary - led extension approaches in Nigeria. World Journal of Agricultural Sciences, 6(4), 353-359.

Akpoko J. G. and Kudi, T.M. (2007). Outcome assessment of university -based rural youths agricultural extension out-reach programme in selected villages of Kaduna State, Nigeria. Journal of Applied Sciences, 7, 3292-3296

Bature,W.M, Sanni, A.A and Adebayo, F.O. (2013). Analysis of Impact of National Fadama Development Project on Beneficiaries' income and wealth in FCT, Nigeria. Journal of agricultural Economics and Sustainable Development, 4(17), 11-24.

Cunningham, P.,Oosthuizen, S., and Taylor, R. (2009). Beyond the lecture hall: universities and community engagement from the middle ages to the present day. Retrieved from htpp:// www.educ.cam.ac.uk/events/conferences/past/beyondthe lecture hall/beyondthe lecture hall virtual book.pdf April 23,2015. 
Creative commons User License: CC BY-NC-ND

Abstracted by: EBSCOhost, Electronic Journals Service (EJS),

Google Scholar, Directory of Open Access Journals (DOAJ),

Journal Seek, Scientific Commons,

Food and Agricultural Organization (FAO), CABI and Scopus
Journal of Agricultural Extension

Vol. XX (X) XXXXXX, 20XX

ISSN(e): 24086851; ISSN(Print); 1119944X

http://journal.aesonnigeria.org

http://www.ajol.info/index.php/jae

Email: editorinchief@aesonnigeria.org

Devereux, S and Maxwell, S. (2001). Food insecurity in Sub -Saharan Africa.I TDG Publishing, Pyerermaritzburg, 361 pp.

Fadiji,T.O. and Adeniji, O.B. (2011) . Problems and prospects of organization and administration of agricultural extension in Nigeria; a critical review. Continental Journal of Agricultural Economics, 5(2), 31-39.

Koyenikan, M. J. (2008) Issues for Agricultural Extension Policy in Nigeria. Projects Coordinating Unit (PCU)/Federal Ministry of Agriculture and Water Resources (FMAWR), Benin City.

Mendelsohn, R.,Morrison, W., Schlesinger, M.E. and Andronova, N.G. (2000). Country specific market impacts from climate change. Climate Change, 45: 553-569

National Bureau of Statistics (2006). Core Welfare Indicator Questionnaire: Federal republic of Nigeria.

Nxumalo, K. K. S. and. Oladele, O. I. (2013). Factors Affecting Farmers'

Participation in Agricultural Programme in Zululand District, Kwazulu Natal

Province, South Africa. Journal of Social Science, 34(1): 83-88 .

Ryff, C. and keyes, C. (1995). The structure of Psychological wellbeing revisited. Journal of Personality and Social Psychology.62 pp

Umeh, O.J.,Ekumankama, O.O. ,Nwachukwu, I., Ekwe, K. C. (2015). Comparative performance Evaluation of the Agricultural Development programmes of Abia and Enugu States. Nigeria Journal of Agricultural Extension Vol. 19(2) 111 pp

Zerihun, G. (2012). Livelihood strategies in rural South Africa: Implications for poverty reduction. Selected paper prepared for presentation at the International Association of Agricultural Economists (IAAE) Triennial Conference, Foz Do Iguacu, Brazil. (2012). 